\title{
HIV integrase variability and genetic barrier in antiretroviral naïve and experienced patients
}

\author{
Antonio Piralla', Stefania Paolucci ${ }^{1}$, Roberto Gulminetti ${ }^{2}$, Giuditta Comolli ${ }^{1,3}$ and Fausto Baldanti ${ }^{*}$
}

\begin{abstract}
Background: HIV-1 integrase (IN) variability in treatment naïve patients with different HIV-1 subtypes is a major issue. In fact, the effect of previous exposure to antiretrovirals other than IN inhibitors (INI) on IN variability has not been satisfactorily defined. In addition, the genetic barrier for specific INI resistance mutations remains to be calculated.

Methods: IN variability was analyzed and compared with reverse transcriptase (RT) and protease (PR) variability in 41 treatment naïve and 54 RT inhibitor (RTI) and protease inhibitor (PRI) experienced patients from subjects infected with subtype B and non-B strains. In addition, four HIV-2 strains were analyzed in parallel. Frequency and distribution of IN mutations were compared between HAART-naïve and RTI/PI-experienced patients; the genetic barrier for 27 amino acid positions related to INI susceptibility was calculated as well.
\end{abstract}

Results: Primary mutations associated with resistance to INI were not detected in patients not previously treated with this class of drug. However, some secondary mutations which have been shown to contribute to INI resistance were found. Only limited differences in codon usage distribution between patient groups were found. HIV-2 strains from INI naive patients showed the presence of both primary and secondary resistance mutations.

Conclusion: Exposure to antivirals other than INI does not seem to significantly influence the emergence of mutations implicated in INI resistance. HIV-2 strain might have reduced susceptibility to INI.

\section{Background}

Raltegravir (MK-0518; Isentress, Merck) was the first integrase (IN) inhibitor approved for treatment of HIV infection [1], while other compounds such as GS-9137 [2], S-1360 [3], and L-870,810 [4] are at different stages of development. Raltegravir (RAL) has shown potent and durable antiretroviral activity in both treatment naïve $[5,6]$ and highly experienced HIV-1-infected individuals. Due to its novel mechanism of action, RAL was shown to be effective also against HIV-1 strains resistant to reverse transcriptase (RT), protease (PR) and entry inhibitors, both in vitro [7] and in vivo [8,9]. However, it has been observed that failure of highly active antiretroviral therapy (HAART) including RAL might be related to the emergence of drug-resistant virus variants [10-15], and amino acid changes associated with resistance to integrase inhibitors (INI) have been reported [16-18].

\footnotetext{
* Correspondence: segreteria.virologia@smatteo.pv.it

1 Molecular Virology Unit, Virology and Microbiology Department, Fondazione IRCCS Policlinico San Matteo, 27100 Pavia, Italy

Full list of author information is available at the end of the article
}

In particular, Y143R/C, N155H and Q148K/R/H have been identified as primary RAL resistance mutations, usually associated with secondary mutations often already present at baseline [10,12, and 13]. However, the entire panel of mutations associated with RAL resistance has not been fully ascertained. Nor do we fully understand the potential impact of naturally occurring ancillary mutations with respect to: i) promotion of RAL resistance associated mutations, ii) improvement of the activity of mutated IN and iii) HIV-1 replicative capacity. In addition, it is unclear whether drug pressure on the Pol gene by RT and PR inhibitors might influence the emergence of primary or ancillary RAL mutations. Finally, it has been observed that about $20 \%$ of new HIV infections are now sustained in Italy by a wide variety of subtype non-B HIV-1 strains and a few HIV-2 strains [19,20]. Thus, it is important to define the variability of the IN gene in treatment-naïve and HAART-experienced patients in different HIV-1 subtypes.

The aims of the study were: i) to evaluate IN variability and polymorphism distribution among patients naïve

\section{() Biomed Central}

(c) 2011 Piralla et al; licensee BioMed Central Ltd. This is an Open Access article distributed under the terms of the Creative Commons Attribution License (http://creativecommons.org/licenses/by/2.0), which permits unrestricted use, distribution, and reproduction in any medium, provided the original work is properly cited. 
for RAL treatment; ii) to better understand whether previous HAART treatment not including RAL might be associated with the emergence of mutations conferring resistance to INI; iii) to calculate the genetic barrier of primary and secondary mutations associated with INI resistance in different HIV-1 subtypes.

\section{Materials and methods Patients}

IN variability was analyzed using stored plasma samples from 95 consecutive patients infected with HIV-1, as well as four HIV-2 positive patients referred to our Institution in the period December 2008 - December 2009. Patients with no available plasma samples or viral load $<1,000$ HIV RNA copies/ml plasma were excluded from the analysis. Eligible patients were stratified on the basis of treatment history as follows: i) HAART-naïve patients, ii) RT and PR inhibitor-experienced but RALnaïve (RTI/PI-experienced).

\section{Real-time RT-PCR, RT-PCR and sequencing}

HIV-1 plasma RNA levels were determined using the Versant HIV-1 RNA 3.0 Assay (Bayer, NY, USA), while HIV-2 plasma RNA levels were determined according to an in house developed real-time RT PCR [21]. For IN gene sequencing (codons 1-277), a region of the HIV-1 Pol gene was amplified in a nested-RT-PCR using primers Int1F, 5'- CAT GGG TAC CAG CAC ACA CAA AGG-3' and Int1R, 5'-CCA TGT TCT AAT CCT CAT CCT GTC -3 ' for the first PCR round, while primers Int2F 5'-GGA ATT GGA GGA AAT GAA CAA GTA GAT -3' and Int2R 5'-GCC ACA CAA TCA TCA CCT GCC ATC-3' were used in the second PCR round [12]. The first nested-RT-PCR reaction was performed in 50 $\mu \mathrm{l}$ using the SuperScript ${ }^{\mathrm{TM}}$ III Platinum ${ }^{\circledR}$ One-Step qRT-PCR System (Invitrogen, Carlsbad, CA, USA) with the following thermal profile: $30 \mathrm{~min}$ at $50^{\circ} \mathrm{C}$ and $10 \mathrm{~min}$ at $95^{\circ} \mathrm{C}$ for $1 \mathrm{cycle}, 1 \mathrm{~min}$ at $95^{\circ} \mathrm{C}, 1 \mathrm{~min}$ at $52^{\circ}$ $\mathrm{C}$ and $1 \mathrm{~min}$ and $10 \mathrm{sec}$ at $72^{\circ} \mathrm{C}$ for 50 cycles followed by $10 \mathrm{~min}$ at $72^{\circ} \mathrm{C}$. The nested PCR reaction was performed in $100 \mu \mathrm{l}$ using TaqGold and the relevant buffer (Applied Biosystem, Foster City, CA, USA) with the following thermal profile: $10 \mathrm{~min}$ at $95^{\circ} \mathrm{C}$ for 1 cycle, $1 \mathrm{~min}$ at $95^{\circ} \mathrm{C}, 1 \mathrm{~min}$ at $50^{\circ} \mathrm{C}$, and $1 \mathrm{~min}$ and $10 \mathrm{sec}$ at $72^{\circ} \mathrm{C}$ for 30 cycles, followed by $10 \mathrm{~min}$ at $72^{\circ} \mathrm{C}$ [12]. RT and PR genes were sequenced in parallel [22]. Sequencing of amplicons was performed using an ABI PRISM 3100 Genetic Analyzer ${ }^{\circledR}$ (Applied Biosystem, Foster City, CA, USA) with the ABI PRISMTM Big Dye Terminator Cycle Sequencing Reaction kit.

\section{Sequence analysis}

IN, RT, and PR sequences were analyzed with the MEGA 4.0 version software [23]. Sequence distances were calculated using the Simmonic sequence editor (version 1.6) program [24], with the Kimura 2-Parameter as a distance estimated method. Divergence was defined as the mean proportion of nucleotide or amino acid differences between all sequence pairs. In each patient, only the predominant virus strain was taken into account to calculate variability. Integrase variability was also calculated in three functional domains: N-terminal domain (NTD), catalytic core domain (CCD), and C-terminal domain (CTD).

\section{Genotypic resistance and genetic barrier}

Resistance to antiretrovirals was estimated on the basis of the Stanford HIV drug resistance database report (http:// hivdb.stanford.edu) and the geno2pheno ${ }^{\circledR}$ report (http:// integrase.bioinf.mpi-inf.mpg.de/index.php). Twenty-seven IN positions related to 28 mutations in INI resistant HIV-1 strains were categorized as follows: i) primary mutations (E92Q, F121Y, E138A, G140A/S, Y143R/C/H, S147G, Q148H/R/K, S153Y, N155H, R263K) ii) ancillary mutations (H51Y, T66I, L74A/M/I, Q95K, T97A, E138K, Q146P V151I, E157Q,G163R, I203M, S230R) and iii) mutations with an uncertain role (V72I, T125K, A128Y, K160D, V165I, V201I; http://hivdb. stanford.edu).

The genetic barrier to INI-resistance was calculated in 27 IN amino acid positions with a method previously published by van de Vijver et al. [25]. The smallest number of transitions (scored as 1) or transversions (scored as 2.5) were used to calculate the genetic barrier. The genetic barrier was calculated with the sum of scores obtained for each amino acid position.

\section{Statistical analysis}

Statistical analyses were performed using GraphPad Prism (version 4.0) software (San Diego, CA, USA). To compare the nucleotide and amino acid divergence between groups of patients the Mann Whitney U-test was utilized, while the chi-square test was used for comparing the calculated genetic barrier for major and minor substitutions between groups of patients.

\section{Results}

\section{Study population}

Nucleotide (nt) and amino acid (aa) integrase variability was analyzed in 41 HAART-naïve patients, and 54 RTI/ PI-experienced patients. Four HIV-2 strains were also analyzed. Among HIV-1 strains from HAART-naïve patients, 16 were subtype $B$ and 25 were non-B strains (A, no.3; C, no.5; G, no.3; F, no.6; CRF02AG, no.6; CRF01AE, no.1; CRF12BF, no.1;). Among HIV-1 strains from RTI/PI-experienced patients, 19 were subtype $B$ and 35 were subtype non-B strains (A, no.1; A/K no. 2; C, no.2 D, no.3; G, no.3; D/F, no.1; F, no.11; CRF02AG, 
no.9; CRF01AE, no.2; CRF 19CPX, no.1). For comparison, RT and PR gene sequence variability was analyzed in HAART-naïve and RTI/PI-experienced patients (Table 1). HIV-2 strains were from RTI/PI-experienced patients.

\section{HIV IN, RT, and PR variability}

Both IN nucleotide and amino acid variability was higher in HAART-naïve patients with respect to RTI/PIexperienced patients ( $\mathrm{p}<0.001$; Table 1$)$. Conversely, RT and PR nucleotide variability was higher in RTI/PIexperienced patients with respect to HAART-naïve patients $(\mathrm{p}<0.001)$.

Gene variability in the HIV-1 B and non-B subtypes was also analyzed. In subtype B strains, IN amino acid variability was statistically higher in HAART-naïve patients with respect to RTI/PI-experienced patients $(6.1 \pm 1.5$ vs $4.1 \pm 1.3 ; \mathrm{p}<0.001)$. However, both RT $(8.3 \pm 2.3$ vs $4.5 \pm 1.2 ; \mathrm{p}<0.001)$ and $\mathrm{PR}(20.3 \pm 7.5$ vs $8.9 \pm 2.8 ; \mathrm{p}<0.001)$ amino acid variability was higher in strains from RTI/PI-experienced patients with respect to HAART-naïve patients. In subtype non-B strains, IN amino acid variability was not statistically different in naïve patients with respect to RTI/PRI experienced patients $(6.9 \pm 1.9$ vs $7.1 \pm 1.8 ; \mathrm{p}>0.05)$, whereas $\mathrm{RT}$ $(8.0 \pm 2.2$ vs $7.0 \pm 1.9 ; \mathrm{p}<0.001)$ and PR $(13.3 \pm 6.2$ vs $10.8 \pm 4.1 ; \mathrm{p}<0.001)$ amino acid variability was higher in RTI/PI-experienced patients with respect to HAARTnaïve patients.

In Table 1, the number of conserved and variable amino acid residues of the IN gene in each group of virus strains is shown. The number of conserved residues in sequences from HAART-naïve patients and RTI/PI-experienced patients was comparable (Table 1). No differences between singleton sites and parsimony informative sites were observed among the variable residues in all patient groups (Table 1).

When the three functional domains of the IN gene were individually analyzed, the amino acid sequences from HAART-naïve patients were slightly more conserved than sequences from RTI/PI-experienced patients. In the analysis of amino acid variability in the three structural domains for all sequence categories, a higher variability in the NTD with respect to the CCD and the CTD was observed ( $<<0.001$; data not shown).

\section{Frequency, distribution and genetic barrier of IN resistance mutations}

In Table 2, mutations in positions associated with INI susceptibility are shown. The eight primary mutations associated with RAL or elvitegravir (EGV) resistance were not present in any of the strains from INI-naïve patients.
In the 41 HAART-naïve patients, 6 secondary mutations were found: V72I (22/41, 53.7\%), L74A/M/I (3/41, 7.3\%), E157Q (2/41, 4.9\%), V165I (8/41, 19.5\%), V201I (30/41, 73.2\%) I203M (2/41. 4.9\%) (Table 2). Additionally, five substitutions of unknown significance (T97S, T125A/M/V, S153A, K160Q/R, S230N) were found.

In the $54 \mathrm{RTI} / \mathrm{PI}$-experienced patients, 7 secondary mutations were found: V72I (28/54, 51.9\%), L74A/M/I (4/54, 7.4\%), T97A (2/54, 3.7\%), E157Q (1/54, 1.9\%), V165I (10/54, 18.5\%), V201I (38/54, 70.4\%) and I203M (1/54, 1.9\%; Table 2). Besides, seven substitutions of unknown significance (V72D, Q95R, T125A/V/P, E138D, K160Q, G163E/N/A and S230N; Table 2) were found. No statistical difference in the prevalence of secondary mutations between sequences from HAARTnaïve and RTI/PI-experienced patients was observed $(\mathrm{p}<0.05)$

Analysis of codon usage distribution between sequences from HAART-naïve and RTI/PI-experienced patients showed that there was no significant difference in the INI resistance mutations with the exception of position 148 (Table 3). At this position, a significant difference in predominant codon usage (CAA vs CAG) between sequences from HAART-naïve and RTI/PIexperienced patients was shown $(\mathrm{p}=0.01)$.

\section{HIV-2 variability and mutation distribution}

HIV-2 strains showed higher conservation with respect to HIV-1 subtype B and non-B strains ( $\mathrm{p}<0.001)$. In detail, in HIV-2 strains, 241/273 (88.3\%) conserved sites and 32/ $273(11.7 \%)$ variable sites were observed (Table 1). The analysis of four HIV-2 integrase genes showed that the mean nucleotide and amino acid variability was $13.0 \% \pm$ 1.1 and $7.9 \% \pm 1.4$, respectively. Three out of four HIV-2 strains analyzed (all from RTI/PI-experienced patients but INI naïve) showed the presence of an $\mathrm{E}$ to $\mathrm{T}$ polymorphism, in a position where a primary mutation (E138A normally associated with RAL-resistant HIV-1 strains) was detected. Three secondary mutations I72V, E125D and S163D (Table 2) were also detected.

\section{Discussion}

The introduction of the new INI antiviral-drug class $[6,26]$ is an important step forward in the treatment of HIV-1 infection [8]. Despite the success of HAART in managing HIV-1 infection, the development and worldwide spread of HIV-1 drug resistant strains remain serious issues. In this study, we analyzed the IN gene variability in parallel with $R T$ and PR variability with the aim of evaluating whether HIV genetic background influences the appearance of IN mutations. The distribution of specific amino acids implicated in INI susceptibility was also compared in different HIV-1 subtypes 
Table 1 Conserved and variable amino acid distribution in Integrase sequences and amino acid divergence among RT, PR and IN sequences in HIV-1

\begin{tabular}{|c|c|c|c|c|c|c|c|c|c|c|c|c|}
\hline \multirow[t]{2}{*}{$\begin{array}{l}\text { Category } \\
\text { (strain no.) }\end{array}$} & \multicolumn{3}{|c|}{ Mean nucleotide divergence \pm SD } & \multicolumn{3}{|c|}{ Mean amino acid divergence \pm SD } & \multirow[t]{2}{*}{$\begin{array}{l}\text { IN conserved amino } \\
\text { acid (\%) }\end{array}$} & \multicolumn{2}{|c|}{$\begin{array}{l}\text { IN variable amino } \\
\text { acid (\%) }\end{array}$} & \multicolumn{3}{|c|}{$\begin{array}{l}\text { IN conserved amino acid in three } \\
\text { functional domains (\%) }\end{array}$} \\
\hline & RT gene & PR gene & IN gene & RT gene & PR gene & IN gene & & Singleton $^{\mathrm{a}}$ & Parsimony $^{\mathbf{b}}$ & NTD (1-50) & CCD (51-212) & CTD (213-277) \\
\hline HAART-naïve (41) & $9.2 \pm 2.3$ & $10.5 \pm 2.9$ & $8.8 \pm 2.5$ & $6.3 \pm 1.8$ & $11.3 \pm 3.5$ & $7.0 \pm 1.8$ & $180(65.9)$ & $36(13.2)$ & $57(20.9)$ & $26(52.0)$ & $114(70.4)$ & $40(62.5)$ \\
\hline $\begin{array}{l}\text { RT/PI-experienced } \\
\text { (54) }\end{array}$ & $9.8 \pm 2.5$ & $12.2 \pm 3.6$ & $8.3 \pm 2.5$ & $9.8 \pm 2.6$ & $18.8 \pm 7.8$ & $6.5 \pm 1.9$ & $170(62.3)$ & $39(14.3)$ & $64(23.4)$ & $26(52.0)$ & $103(63.6)$ & $41(64.1)$ \\
\hline $\begin{array}{l}\text { HAART-naïve vs } \\
\text { RT/PI-experienced }\end{array}$ & $p<0.001$ & $p<0.001$ & $p<0.001$ & $p<0.001$ & $p<0.001$ & $p<0.001$ & ns & ns & ns & ns & ns & ns \\
\hline HIV-2 (4) & ND & ND & $13.0 \pm 1.1$ & ND & ND & $7.9 \pm 1.4$ & $241(88.3)$ & $9(3.3)$ & $23(8.4)$ & $39(78.0)$ & 149 (91.9) & $53(82.8)$ \\
\hline HIV-2 vs HIV-1 & & & $p<0.001$ & & & $p<0.001$ & $p<0.001$ & $p<0.001$ & $p<0.001$ & $p<0.001$ & $p<0.001$ & $p<0.001$ \\
\hline
\end{tabular}

SD: standard deviation; ND: not done; ns: not significant; NTD: N-terminal domain; CCD: catalytic core domain; CTD: C-terminal domain; RT: reverse trancriptase; PR: protease; IN: integrase.

${ }^{a}$ A singleton site contains at least two types of amino acid with, at most, one occurring multiple times.

Parsimony-informative if it contains at least two types of amino acid, and at least two of these occur with a minimum frequency of two.

cSignificant p-values are reported. 
Table 2 HIV-1 and HIV-2 amino acid polymorphisms at positions associated with INI (RAL and EGV) resistance

\begin{tabular}{|c|c|c|c|c|c|c|}
\hline \multirow[t]{2}{*}{ Mutation categories } & \multirow[t]{2}{*}{$\begin{array}{l}\text { Known amino } \\
\text { acid substitution }\end{array}$} & \multirow{2}{*}{$\begin{array}{c}\text { Rate of INI resistance } \\
\text { mutations in INI-naïve } \\
\text { patients (\%) }\end{array}$} & \multicolumn{2}{|c|}{$\begin{array}{l}\text { HIV-1 amino acid } \\
\text { substitution }\end{array}$} & \multirow[t]{2}{*}{$\begin{array}{l}\text { HIV-2 clade A ROD } \\
\text { subtype consensus }\end{array}$} & \multirow{2}{*}{$\begin{array}{c}\text { HIV-2 } \\
\text { substitution } \\
\text { (4 strains) }\end{array}$} \\
\hline & & & $\begin{array}{l}\text { HAART- } \\
\text { naïve } \\
(n=41)\end{array}$ & $\begin{array}{c}\text { RTI/PI- } \\
\text { experienced } \\
(n=54)\end{array}$ & & \\
\hline Primary & E92Q & & & & $E$ & \\
\hline \multirow[t]{9}{*}{ mutations } & F121Y & & & & $\mathrm{F}$ & \\
\hline & E138A & & & & $S$ & $T_{3}$ \\
\hline & G140A/S & & & & G & \\
\hline & $\mathrm{Y} 143 \mathrm{R} 7 \mathrm{C} / \mathrm{H}$ & & & & Y & \\
\hline & S147G & & & & S & \\
\hline & $\mathrm{Q} 148 \mathrm{H} / \mathrm{R} / \mathrm{K}$ & & & & Q & \\
\hline & S153Y & & $A_{1}$ & & A & \\
\hline & $\mathrm{N} 155 \mathrm{H}$ & & & & $\mathrm{N}$ & \\
\hline & R263K & & & & $\mathrm{R}$ & \\
\hline \multirow[t]{12}{*}{ Secondary mutations } & H51Y & & & & $\mathrm{H}$ & \\
\hline & T66l & & & & $\mathrm{T}$ & \\
\hline & L74A/M/I & $7(7.4)$ & $\mathrm{I}_{2} / \mathrm{M}_{1}$ & $\mathrm{I}_{4}$ & 1 & \\
\hline & Q95K & & & $\mathrm{R}_{1}$ & $\mathrm{R}$ & \\
\hline & T97A & $2(2.1)$ & $\mathrm{S}_{1}$ & $A_{2}$ & $\mathrm{~T}$ & \\
\hline & E138K & & & $\mathrm{D}_{1}$ & S & $T_{3}$ \\
\hline & Q146P & & & & N & \\
\hline & V151I & & & & V & \\
\hline & E157Q & $3(3.2)$ & $\mathrm{Q}_{2}$ & $\mathrm{Q}_{1}$ & $\mathrm{H}$ & \\
\hline & G163R & & & $E_{2} / N_{1} / A_{1}$ & S & $\mathrm{G}_{2}$ \\
\hline & I203M & $3(3.2)$ & $M_{2}$ & $M_{1}$ & M & \\
\hline & S230R/M & & $\mathrm{N}_{4}$ & $\mathrm{~N}_{2}$ & G & \\
\hline \multirow{6}{*}{$\begin{array}{l}\text { Polymorphic and non- } \\
\text { polymorphic mutations }\end{array}$} & V721 & $50(52.6)$ & $\mathrm{I}_{22}$ & $\mathrm{I}_{28} / \mathbf{D}_{\mathbf{1}}$ & 1 & $V_{2}$ \\
\hline & $\mathrm{T} 125 \mathrm{~K}$ & & $A_{19} / M_{1} / V_{1}$ & $\mathrm{~A}_{24} / \mathrm{V}_{4} / \mathrm{P}_{1}$ & E & $\mathrm{D}_{2}$ \\
\hline & $\mathrm{A} 128 \mathrm{~T}$ & & & & M & \\
\hline & K160D & & $Q_{1} / R_{1}$ & $\mathrm{Q}_{1}$ & $\mathrm{~N}$ & \\
\hline & V165I & 18 (18.9) & $1_{8}$ & $\mathrm{l}_{10}$ & 1 & \\
\hline & V201I & 68 (71.6) & $1_{30}$ & $I_{38}$ & I & \\
\hline
\end{tabular}

RTI: reverse trancriptase inhibitor; PI: protease inhibitor; INI: integrase inhibitor. New polymorphisms are reported in boldface.

and in patients naive for treatment or exposed to RTI and PI. The simultaneous evaluation of RT, PR and IN identity showed that the IN gene had lower amino acid variability. This would confirm the high level of integrase sequence conservation reported by Rhee et al. [27]. Moreover, the analysis of three functional integrase domains showed only a small difference in the catalytic core domain.

The evaluation of IN variability in different patient categories showed no differences in subtype non-B and a higher divergence in subtype B strains from HAARTnaïve compared with RTI/PI-experienced patients. These results are in contrast with the previously reported greater amino acid IN divergence in RT/PIexperienced patients [28]. On the other hand, we observed a greater RT and PR amino acid divergence in both $B$ and non-B strains from RTI/PI-experienced patients with respect to HAART-naïve patients. These findings are consistent with the hypothesis that multiple rounds of positive selection by subsequent HAART regimens including different RTI and PI, may lead to the emergence of a wider number of RT and PR variants in contrast with little or no change in the IN gene.

In keeping with previous studies [13,29-32] no primary IN mutations associated with INI susceptibility were present in strains from INI-naïve patients. 
Table 3 Codon distribution and calculated genetic barrier at 27 integrase inhibitor susceptible positions in HIV-1 INI-naïve patients

\begin{tabular}{|c|c|c|c|c|c|c|c|c|c|c|c|c|c|}
\hline \multirow{2}{*}{$\begin{array}{l}\text { IN codon } \\
\text { position }\end{array}$} & \multirow[t]{2}{*}{ Substitution } & \multirow{2}{*}{$\begin{array}{l}\text { Wild } \\
\text { type } \\
\text { codon }\end{array}$} & \multicolumn{2}{|c|}{ Codon $\%$ distribution } & \multirow{2}{*}{$\begin{array}{l}\text { Mutational } \\
\text { resistance } \\
\text { codon }\end{array}$} & \multirow{2}{*}{$\begin{array}{l}\text { Lower } \\
\text { score }\end{array}$} & \multirow{2}{*}{$\begin{array}{l}\text { IN codon } \\
\text { position }\end{array}$} & \multirow[t]{2}{*}{ Substitution } & \multirow{2}{*}{$\begin{array}{l}\text { Wild } \\
\text { type } \\
\text { codon }\end{array}$} & \multicolumn{2}{|c|}{ Codon $\%$ distribution } & \multirow{2}{*}{$\begin{array}{l}\text { Mutational } \\
\text { resistance } \\
\text { codon }\end{array}$} & \multirow{2}{*}{$\begin{array}{l}\text { Lower } \\
\text { scores }\end{array}$} \\
\hline & & & $\begin{array}{c}\text { HAART- } \\
\text { naïve } \\
(n=41)\end{array}$ & $\begin{array}{c}\mathrm{RTI} / \mathrm{PI}- \\
\text { experienced } \\
(\mathrm{n}=54)\end{array}$ & & & & & & $\begin{array}{l}\text { HAART- } \\
\text { naïve } \\
(n=41)\end{array}$ & $\begin{array}{c}\mathrm{RTI} / \mathrm{PI}- \\
\text { experienced } \\
(\mathrm{n}=54)\end{array}$ & & \\
\hline \multirow[t]{2}{*}{51} & H51Y & CAT & 98 & 100 & TAT & 1 & 143 & $\mathrm{Y} 143 \mathrm{C}$ & TAC & 90 & 90 & TGC & 1 \\
\hline & & CAC & 2 & 0 & TAC & 1 & & & TAT & 10 & 10 & TGT & 1 \\
\hline \multirow[t]{3}{*}{66} & T66l & ACA & 98 & 94 & ATA & 1 & & Y143R & TAC & 90 & 90 & CGC & 2 \\
\hline & & ACC & 0 & 6 & ATC & 1 & & & TAT & 10 & 10 & CGT & 2 \\
\hline & & ACG & 2 & 0 & ATA & 2 & 146 & Q146P & CAA & 98 & 98 & CCG & 2.5 \\
\hline \multirow[t]{8}{*}{72} & V721 & GTT & 32 & 31 & ATT & 1 & & & CAG & 2 & 2 & CCA & 2.5 \\
\hline & & GTC & 15 & 6 & ATC & 1 & & Q146K & CAA & 98 & 98 & AAA & 2.5 \\
\hline & & GTA & 0 & 6 & ATA & 1 & & & CAG & 2 & 2 & AAG & 2.5 \\
\hline & & GTG & 0 & 4 & ATA & 2 & 147 & $\mathrm{~S} 147 \mathrm{G}$ & AGT & 76 & 70 & GGT & 1 \\
\hline & 172 & ATT & 41 & 45 & & 0 & & & AGC & 24 & 30 & GGC & 2 \\
\hline & & ATC & 12 & 2 & & 0 & 148 & Q148H & CAA & 80 & 96 & CAT/C & 2.5 \\
\hline & & ATA & 0 & 4 & & 0 & & & CAG & 20 & 4 & CAT/C & 2.5 \\
\hline & D72 & GAT & 0 & 2 & ATT & 3.5 & & Q148K & CAA & 80 & 96 & AAA & 2.5 \\
\hline \multirow[t]{7}{*}{74} & L74I & $\mathrm{CTG}$ & 72 & 78 & ATA & 3.5 & & & CAG & 20 & 4 & AAG & 2.5 \\
\hline & & CTA & 10 & 15 & ATA & 2.5 & & Q148R & CAA & 80 & 96 & CGA & 1 \\
\hline & & TTA & 10 & 2 & ATA & 2.5 & & & CAG & 20 & 4 & CGG & 1 \\
\hline & & $\pi \mathrm{T}$ & 2 & 0 & ATA & 3.5 & 151 & V151I & GTA & 71 & 72 & ATA & 1 \\
\hline & 174 & ATT & 0 & 0 & & 0 & & & GTG & 29 & 28 & ATA & 2 \\
\hline & & ATA & 2 & 7 & & 0 & 153 & S153Y & TCT & 76 & 87 & TAT & 2.5 \\
\hline & M74 & ATG & 2 & 0 & ATA & 1 & & & TCC & 15 & 11 & TAC & 2.5 \\
\hline \multirow[t]{2}{*}{92} & E92Q & GAA & 63 & 61 & CAA & 2.5 & & & TCA & 7 & 2 & TAT/C & 5 \\
\hline & & GAG & 37 & 39 & CAG & 2.5 & & A153 & GCC & 2 & 0 & TAC & 5 \\
\hline \multirow[t]{3}{*}{95} & Q95K & CAA & 32 & 28 & AAA & 2.5 & 155 & $\mathrm{~N} 155 \mathrm{H}$ & AAT & 90 & 93 & CAT & 2.5 \\
\hline & & CAG & 68 & 70 & AAG & 2.5 & & & $A A C$ & 10 & 7 & CAC & 2.5 \\
\hline & R95 & CGG & 0 & 2 & AAG & 3.5 & & N155S & AAT & 90 & 93 & AGT & 1 \\
\hline \multirow[t]{3}{*}{97} & T97A & ACA & 98 & 96 & GCA & 1 & & & AAC & 10 & 7 & AGC & 1 \\
\hline & A97 & GCA & 0 & 4 & & 0 & 157 & E157Q & GAA & 88 & 91 & CAA & 2.5 \\
\hline & S97 & TCA & 2 & 0 & GCA & 2.5 & & & GAG & 7 & 7 & CAG & 2.5 \\
\hline \multirow[t]{2}{*}{121} & F121Y & $T T C$ & 90 & 98 & TAC & 2.5 & & Q157 & CAA & 5 & 2 & & 0 \\
\hline & & $\pi T$ & 10 & 2 & TAT & 2.5 & 160 & K160D & AAA & 85 & 93 & GAT/C & 3.5 \\
\hline \multirow[t]{4}{*}{125} & $\mathrm{~T} 125 \mathrm{~K}$ & ACA & 27 & 18 & AAG & 2.5 & & & AAG & 11 & 5 & GAT/C & 3.5 \\
\hline & & ACT & 10 & 4 & $\mathrm{AAA} / \mathrm{G}$ & 5 & & R160 & AGA & 2 & 0 & GAT & 4.5 \\
\hline & & ACG & 12 & 24 & AAG & 2.5 & & Q160 & CAA & 2 & 2 & GAT/C & 5 \\
\hline & A125 & GCA & 44 & 33 & AAA & 3.5 & 163 & G163R & GGA & 63 & 57 & AGA & 1 \\
\hline
\end{tabular}


Table 3 Codon distribution and calculated genetic barrier at 27 integrase inhibitor susceptible positions in HIV-1 INI-na?i?ve patients (Continued)

\begin{tabular}{|c|c|c|c|c|c|c|c|c|c|c|c|c|c|}
\hline & & GCG & 2 & 6 & $A A G$ & 3.5 & & & $\overline{G G G}$ & 27 & 39 & $A G G$ & 1 \\
\hline & & $\mathrm{GCT}$ & 0 & 6 & $\mathrm{AAA} / \mathrm{G}$ & 6 & & & GGT & 0 & 2 & $C G C, A G A / G$ & 3.5 \\
\hline & V125 & GTG & 0 & 7 & $A A G$ & 3.5 & & E163 & GAA & 0 & 4 & AGA & 2 \\
\hline & & GTA & 2 & 0 & AAA & 3.5 & & N163 & AAC & 0 & 2 & $C G C, A G A / G$ & 3.5 \\
\hline & M125 & ATG & 2 & 0 & AAG & 2.5 & & A163 & GCG & 0 & 2 & $\mathrm{CTG}, \mathrm{AGG}$ & 3.5 \\
\hline & $\mathrm{P} 125$ & CCG & 0 & 2 & AAG & 5 & 165 & V165I & GTA & 56 & 52 & ATA & 1 \\
\hline \multirow[t]{3}{*}{128} & $\mathrm{~A} 128 \mathrm{~T}$ & GCA & 54 & 50 & ACA & 1 & & & GTC & 22 & 18 & ATC & 1 \\
\hline & & GCC & 37 & 46 & ACC & 1 & & & $\mathrm{GTT}$ & 2 & 10 & $A T T$ & 1 \\
\hline & & $\mathrm{GCT}$ & 9 & 4 & $\mathrm{ACT}$ & 1 & & & GTG & 0 & 2 & ATA & 2 \\
\hline \multirow[t]{2}{*}{138} & E138K & GAA & 100 & 98 & AAA & 1 & & 1165 & ATA & 20 & 18 & & 0 \\
\hline & D138 & GAC & 0 & 2 & $\mathrm{AAA} / \mathrm{G}$ & 3.5 & 201 & V201I & GTA & 24 & 28 & ATA & 1 \\
\hline \multirow[t]{8}{*}{140} & G140S & GGA & 46 & 37 & AGT/C & 3.5 & & & GTG & 2 & 2 & ATA & 2 \\
\hline & & GGC & 44 & 46 & $A G C$ & 1 & & 1201 & ATA & 74 & 70 & & 0 \\
\hline & & GGT & 5 & 6 & AGT & 1 & 203 & $1203 \mathrm{M}$ & ATA & 95 & 98 & ATG & 1 \\
\hline & & GGG & 5 & 9 & AGT/C & 3.5 & & M203 & ATG & 5 & 2 & & 0 \\
\hline & G140A & GGA & 46 & 37 & GCA & 2.5 & 230 & S230R & AGC & 90 & 96 & AAC & 1 \\
\hline & & GGC & 44 & 46 & GCC & 2.5 & & N230 & AAC & 10 & 4 & & 0 \\
\hline & & GGT & 5 & 6 & $\mathrm{GCT}$ & 2.5 & 263 & R263K & AGA & 85 & 96 & AAA & 1 \\
\hline & & GGG & 5 & 6 & $\mathrm{GCT} / \mathrm{G}$ & 2.5 & & & AGG & 15 & 4 & AAG & 1 \\
\hline
\end{tabular}


However, in sequences from INI-naïve patients some secondary mutations, which have been shown to contribute to RAL resistance [28-31], were found. The low prevalence and the equal distribution of these polymorphisms among the different groups of patients are in contrast with the reported appearance of secondary mutations in association with prior antiretroviral exposure $[28,31]$. Thus, our results are in accordance with findings by Garrido et al., [32] and suggest that the emergence of RAL resistance mutations is weakly influenced by prior exposure to antiretrovirals other than INI.

Finally, new polymorphisms (Q95R, and T97S) in positions related to INI resistance were found. Whether and how these mutations might influence viral fitness or replication remains to be clarified.

The genetic barrier was calculated for 27 amino acid positions related to INI susceptibility. The majority of these positions were highly conserved. Our analysis extends the results reported by Maïga et al [33] (including only B and CRFD02_AG subtypes) to a wider collection of HIV-1 subtypes which reflects the evolving epidemiology of this infection in our region [19]. Analysis of codon usage distribution between sequences from HAART-naïve and RTI/PI-experienced patients revealed a single position (148), with a predominant difference in codon usage. These findings suggest a marginal yet valid influence of prior antiretroviral exposure on the genetic barrier in our study population [33]. A larger dataset would allow better definition of the role played by previous treatment with RTI and PI on INI susceptibility. On the other hand, the great majority of patients on HAART show complete suppression of peripheral viral load, and the enrollment of 95 viremic patients required 1 year to be completed.

Due to the small number of HIV-2 sequences, our analysis did not allow us to draw conclusions on HIV-2 variability. However, of particular interest was the detection of mutations in IN positions associated with RAL resistance. This finding confirms and extends a previous observation by $\mathrm{Xu}$ et al. [34]. The identification of INIresistance mutations in INI-naive patients infected with HIV-2 highlights the urgent need for future studies on HIV-2 and may necessitate avoidance of INI in the treatment of these patients.

In conclusion, primary INI resistance-associated mutations were not present in this population of INI naïve HIV-1 infected individuals. Exposure to antivirals other than INI does not seem to significantly influence the emergence of mutations implicated in INI resistance.

\section{Acknowledgements}

We thank all the technical staff of the Virology Unit, Laurene Kelly for revision of the English, and Daniela Sartori for editing. This work was partially supported by the Ministero della Salute, Ricerca Corrente 80207 and Programma Nazionale AIDS (convenzione 40H55).

\section{Author details}

${ }^{1}$ Molecular Virology Unit, Virology and Microbiology Department, Fondazione IRCCS Policlinico San Matteo, 27100 Pavia, Italy. ${ }^{2}$ Institute of Infectious Diseases, Fondazione IRCCS Policlinico San Matteo, 27100 Pavia, Italy. ${ }^{3}$ Experimental Research Laboratories, Biotechnology Area, Fondazione IRCCS Policlinico San Matteo, 27100 Pavia, Italy.

\section{Authors' contributions}

AP has made great contribution to sequences analysis and manuscript preparation. SP and RG have been involved in sample collection and sequencing. GC has been involved in sample collection. FB has contributed in manuscript preparation and fund raising.

All authors read and approved the final manuscript.

\section{Competing interests}

The authors declare that they have no competing interests.

Received: 19 January 2011 Accepted: 31 March 2011

Published: 31 March 2011

\section{References}

1. Anker M, Corales RB: Raltegravir (MK-0518): a novel integrase inhibitor for the treatment of HIV infection. Expert Opin Investig Drugs 2008, 17:97-103.

2. DeJesus E, Berger D, Markowitz M, Cohen C, Hawkins T, Ruane P, Elion R, Farthing C, Zhong L, Cheng AK, McColl D, Kearney BP, for the 183-0101 Study Team: Antiviral activity, pharmacokinetics, and dose response of HIV-1 integrase inhibitor GS-9137 (JTK-303) in treatment-naïve and treatment-experienced patients. J Acquir Immune Defic Syndr 2006, 43:1-5.

3. Billich A: S-1360 Shionogi-GlaxoSmithKline. Curr Opin Investig Drugs 2003, 4:206-209.

4. Egbertson MS, Moritz HM, Melamed JY, Han W, Perlow DS, Kuo MS, Embrey M, Vacca JP, Zrada MM, Cortes AR, Wallace A, Leonard $Y$, Hazuda DJ, Miller MD, Felock PJ, Stillmock KA, Witmer MV, Schleif W, Gabryelski LJ, Moyer G, Ellis JD, Jin L, Xu W, Braun MP, Kassahun K, Tsou NN, Young SD: A potent orally active HIV-1 integrase inhibitor. Bioorg Med Chem Lett 2007, 17:1392-1398.

5. Markowitz M, Morales-Ramirez JO, Nguyen BY, Kovacs CM, Steigbigel RT, Cooper DA, Liporace R, Schwartz R, Isaacs R, Gilde LR, Wenning L, Zhao J, Teppler H: Antiretroviral activity, pharmacokinetics, and tolerability of MK-0518, a novel inhibitor of HIV-1 integrase, dosed as monotherapy for 10 days in treatment-naïve HIV-1-infected individuals. J Acquir Immune Defic Syndr 2006, 43:509-515.

6. Markowitz M, Nguyen BY, Gotuzzo E, Mendo F, Ratanasuwan W, Kovacs C, Prada G, Morales-Ramirez JO, Crumpacker CS, Isaacs RD, Gilde LR, Wan H, Miller MD, Wenning LA, Teppler H, Protocol 004 Part II Study Team: Rapid and durable antiretroviral effect of the HIV-1 integrase inhibitor raltegravir as part of combination therapy in treatment-naïve patients with HIV-1 infection: results of a 48-week controlled study. J Acquir Immune Defic Syndr 2007, 46:125-133.

7. Lee DJ, Robinson WE Jr: Human immunodeficiency virus type 1 (HIV-1) integrase: resistance to diketo acid integrase inhibitors impairs HIV-1 replication and integration and confers cross-resistance to L-chicoric acid. J Virol 2004, 78:5841-5847.

8. Grinsztejn B, Nguyen BY, Katlama C, Gatell JM, Lazzarin A, Vittecoq D, Gonzalez CJ, Chen J, Harvey CM, Isaacs RD, Protocol 005 Team: Safety and efficacy of the HIV-1 integrase inhibitor raltegravir (MK-0518) in treatment-experienced patients with multidrug-resistant virus: a phase II randomised controlled trial. Lancet 2007, 369:1261-1269.

9. Di Biagio A, Bruzzone B, Rosso R, Viganò O, Icardi G, Viscoli C, Rusconi S: Successful rescue therapy with raltegravir (MK-0518) and Etravirine (TMC125) in an HIV-infected patient failing all four classes of antiretroviral drugs. AIDS Patient Care STDS 2008, 22:415-417.

10. Cooper DA, Steigbigel RT, Gatell JM, Rockstroh JK, Katlama C, Yeni P, Lazzarin A, Clotet B, Kumar PN, Eron JE, Shechter M, Markowitz M, Loutfy MR, Lennox JL, Zhao J, Chen J, Ryan DM, Rand RR, Killar JA, Gilde LR, Strohmaier KM, Meibohm AR, Miller MD, Hazuda DJ, Nessly ML, DiNubile MJ, Isaacs RD, Teppler H, Nguyen BY, for the BENCHMRK Study 
Teams: Subgroup and resistance analyses of raltegravir for resistant HIV1 infection. N Engl J Med 2008, 419:355-365.

11. Malet I, Delelis O, Valantin MC, Montes B, Soulie C, Wirden M, Tchertanov L, Peytavin G, Reynes J, Mouscadet JF, Katlama C, Calvez V, Marcelin AG: Mutations associated with failure of raltegravir treatment affect integrase sensitivity to the inhibitor in vitro. J Antimicrob Agents Chemother 2008, 52:1411-1418.

12. Baldanti F, Paolucci $S$, Gulminetti R, Brandolini M, Barbarini G, Maserati R: Early emergence of raltegravir resistance mutations in patients receiving HAART salvage regimens. J Med Virol 2010, 82:116-122.

13. Canducci Filippo, Sampaolo Michela, Maria Chiara Marinozzi, Boeri Enzo, Spagnuolo Vincenzo, Galli Andrea, Castagna Antonella, Lazzarina Adriano, Clementia Massimo, Gianotti Nicola: Dynamic patterns of human immunodeficiency virus type 1 integrase gene evolution in patients failing raltegravir-based salvage terapie. AIDS 2009, 23:455-460.

14. Lataillade M, Chiarella J, Kozal MJ: Natural polymorphism of the HIV-1 integrase gene and mutations associated with integrase inhibitor resistance. Antivir Ther 2007, 12:563-570.

15. Kobayashi M, Nakahara K, Seki T, Miki S, Kawauchi S, Suyama A, WakasaMorimoto C, Kodama M, Endoh T, Oosugi E, Matsushita Y, Murai H, Fujishita T, Yoshinaga T, Garvey E, Foster S, Underwood M, Johns B, Sato A, Fujiwara T: Selection of diverse and clinically relevant integrase inhibitorresistant human immunodeficiency virus type 1 mutants. Antiviral Res 2008, 80:213-222.

16. Fikkert V, Van Maele B, Vercammen J, Hantson A, Van Remoortel B, Gurnari MM, Pannecouque C, De Maeyer M, Engelborghs Y, De Clercq E, Debyser Z, Witvrouw M: Development of resistence against diketo derivatives of human immunodeficiency virus type 1 by progressive accumulation of integrase mutations. J Virol 2003, 77:11459-11470.

17. Hombrouck A, Voet A, Van Remoortel B, Desadeleer C, De Mayer M, Debyser Z, Witvrouw M: Mutations in human immunodeficiency virus type 1 integrase confer resistance to the Naphthyridine L870,810 and cross resistence to the clinical trial drug GS-9137. Antimicrob Agents Chemother 2008, 52:2069-2078.

18. Canducci F, Marinozzi MC, Sampaolo M, Boeri E, Spagnuolo V, Gianotti N, Castagna A, Paolucci S, Baldanti F, Lazzarin A, Clementi M: Genotypic/ phenotypic patterns of HIV-1 integrase resistance to raltegravir. J Antimicrob Chemother 2010, 65:425-433.

19. Baldanti F, Paolucci S, Ravasi G, Maccabruni A, Moriggia A, Barbarini G, Maserati R: Changes in circulation of $B$ and non-B HIV strains: spotlight on a reference centre for infectious diseases in Northern Italy. J Med Virol 2008, 80:947-952.

20. Riva C, Lai A, Caramma I, Corvasce S, Violin M, Dehò L, Prati F, Rossi C, Colombo MC, Capetti A, Franzetti M, Rossini V, Tambussi G, Ciccozzi M, Suligoi B, Mussini C, Rezza G, Balotta C: Transmitted HIV Type 1 drug resistance and Non-B subtypes prevalence among seroconverters and newly diagnosed patients from 1992 to 2005 in Italy. AIDS Res Hum Retroviruses 2010, 26:41-49.

21. Costarelli S, Torti C, Rodella A, Baldanti F, Paolucci S, Lapadula G, Manca N, Quiros-Roldan E, Izzo I, Carosi G: Screening and management of HIV-2 infected individuals in Northern Italy. AIDS Patient Care STDS 2008, 22:489-494.

22. Paolucci S, Baldanti F, Zavattoni M, Comolli G, Labò N, Menzo S, Clementi M, Gerna G: Comparison of levels of HIV-1 resistance to protease inhibitors by recombinant versus conventional virus phenotypic assay and two genotypic interpretation procedures in treatment-naïve and HAART-experienced HIV-infected patients. J Antimicrob Chemother 2003, 51:135-139.

23. Tamura K, Dudley J, Nei M, Kumar S: MEGA4: molecular evolutionary genetics analysis (MEGA) software version 4. Mol Biol Evol 2007, 24:1596-1599.

24. Simmonds P: Recombination and selection in the evolution of picornaviruses and other mammalian positive-stranded RNA viruses. J Virol 2006, 80:11124-11140.

25. Van de Vijver DA, Wensing AM, Angarano G, Asjö B, Balotta C, Boeri E, Camacho R, Chaix ML, Costagliola D, De Luca A, Derdelinckx I, Grossman Z, Hamouda O, Hatzakis A, Hemmer R, Hoepelman A, Horban A, Korn K, Kücherer C, Leitner T, Loveday C, MacRae E, Maljkovic I, de Mendoza C, Meyer L, Nielsen C, Op de Coul EL, Ormaasen V, Paraskevis D, Perrin L, Puchhammer-Stöckl E, Ruiz L, Salminen M, Schmit JC, Schneider F,
Schuurman R, Soriano V, Stanczak G, Stanojevic M, Vandamme AM, Van Laethem K, Violin M, Wilbe K, Yerly S, Zazzi M, Boucher CA: The calculated genetic barrier for antiretroviral drug resistance substitution is largely similar for different HIV-1 subtypes. J Acquir Immune Defic Syndr 2006, 41:352-360.

26. Steigbigel RT, Cooper DA, Kumar PN, Eron JE, Schechter M, Markowitz M, Loutfy MR, Lennox JL, Gatell JM, Rockstroh JK, Katlama C, Yeni P, Lazzarin A, Clotet B, Zhao J, Chen J, Ryan DM, Rhodes RR, Killar JA, Gilde LR, Strohmaier KM, Meibohm AR, Miller MD, Hazuda DJ, Nessly ML, DiNubile MJ, Isaacs RD, Nguyen BY, Teppler H, BENCHMRK Study Teams: Raltegravir with optimized background therapy for resistant HIV-1 infection. N Eng J Med 2008, 419:339-354.

27. Rhee SY, Liu TF, Kiuchi M, Zioni R, Gifford RJ, Holmes SP, Shafer RW: Natural variation of HIV-1 group $M$ integrase: implications for a new class of antiretroviral inhibitors. Retrovirology 2008, 5:74.

28. van Hal SJ, Herring B, Deris Z, Wang B, Saksena NK, Dwyer DE: HIV-1 integrase polymorphisms are associated with prior antiretroviral drug exposure. Retrovirology 2009, 6:12.

29. Ceccherini-Silberstein F, Malet I, Fabeni L, Dimonte S, Svicher V, D'Arrigo R, Artese A, Costa G, Bono S, Alcaro S, Monforte A, Katlama C, Calvez V, Antinori A, Marcelin AG, Perno CF: Specific HIV-1 integrase polymorphisms change their prevalence in untreated versus antiretroviral-treated HIV-1-infected patients, all naive to integrase inhibitors. J Antimicrob Chemother 2010, 65:2305-2318.

30. Arruda $L B$, Fonseca LA, Duarte AJ, Casseb J: Genetic diversity on the integrase region of the pol gene among HIV type 1-infected patients naive for integrase inhibitors in São Paulo City, Brazil. AIDS Res Hum Retroviruses 2010, 26:105-107.

31. Sichtig N, Sierra S, Kaiser R, Däumer M, Reuter S, Schülter E, Altmann A, Fätkenheuer G, Dittmer U, Pfister H, Esser S: Evolution of raltegravir resistance during therapy. J Antimicrob Chemother 2009, 64:25-32.

32. Garrido C, Geretti AM, Zahonero N, Booth C, Strang A, Soriano V, De Mendoza C: Integrase variability and susceptibility to HIV integrase inhibitors: impact of subtypes, antiretroviral experience and duration of HIV infection. J Antimicrob Chemother 2010, 65:320-326.

33. Maïga Al, Malet I, Soulie C, Derache A, Koita V, Amellal B, Tchertanov L, Delelis O, Morand-Joubert L, Mouscadet JF, Murphy R, Cissé M, Katlama C, Calvez V, Marcelin AG: Genetic barriers for integrase inhibitor drug resistance in HIV type-1 B and CRF02_AG subtypes. Antivir Ther 2009, 14:123-129.

34. Xu L, Anderson J, Ferns B, Cook P, Wildfire A, Workman J, Graham S, Smit E: Genetic diversity of integrase (IN) sequences in antiretroviral treatmentNaïve and Treatment-experienced HIV type 2 patients. AIDS Res Hum Retroviruses 2008, 28:1003-1007.

doi:10.1186/1743-422X-8-149

Cite this article as: Piralla et al: HIV integrase variability and genetic barrier in antiretroviral naïve and experienced patients. Virology Journal $20118: 149$

\section{Submit your next manuscript to BioMed Central and take full advantage of:}

- Convenient online submission

- Thorough peer review

- No space constraints or color figure charges

- Immediate publication on acceptance

- Inclusion in PubMed, CAS, Scopus and Google Scholar

- Research which is freely available for redistribution

Submit your manuscript at www.biomedcentral.com/submit
C Biomed Central 